\title{
Water intake following capture and deprivation in southwestern rodents'
}

\author{
ROBERT BOICE AND CAROL BOICE, DEPARTMENT OF \\ PSYCHOLOGY, OHIO UNIVERSITY, Athens, Ohio 45301
}

Unrestricted and time restricted water intake were compared in eight species of rodents for 200 days. Intake in either condition appeared to be related to water needs in nature. Intake following restricted periods was similar to intake following capture, suggesting that relative deprivation is a cause of high water intake in newly captive rodents.

The primary water source for most rodents is the fluid in their food (Chew, 1965). Introduction of a wild rodent to the unnatural confines of the laboratory produces two interesting demands on the water balance of the captive: First, a confrontation with dry food but an unlimited supply of free standing water should necessitate satisfying thirst by drinking water. Second, stress of the laboratory may induce an abnormal thirst until the captive habituates to his new surrounds (Richter \& Mosier, 1954). This study investigated drinking behaviors in newly captive rodents from arid and semi-arid habitats.

Method

Six wild-caught adults of each of the following species were Ss: pack rats-Neotoma micropus, $N$. albigula, and $N$. mexicana; kangaroo rats-Dipodomys ordii; grasshopper mice-Onychomys leucogaster; chipmunks-Eutamias quadrivittatus; and cotton rats-Sigmodon hispidus. All but the latter, which were trapped in San Antonio, Texas, were collected in the vicinity of Albuquerque, New Mexico. Three Rattus norvegicus from Albuquerque were supplemented with six conspecifics from Ohio. The laboratory was air cooled and the relative humidity ranged between 20 and $50 \%$. All animals were housed in individual cages from time of capture with ad lib. Wayne Breeder Blox (see Hatton \& O'Kelly, 1965).

Water intake from inverted Nalgene graduated cylinders was measured in five successive periods: (1) unrestricted water availability (50 dajys), (2) $1 \mathrm{~h}$ per day availability (50 days), (3) unrestricted availability (50 days), (4) $1 \mathrm{~h}$ per day availability (30 days), and (5) unrestricted availability ( 20 days).

Results and Discussion

All species except the $N$. mexicana survived in apparent good health with air dried food and drinking water (Fig. 1). Overall intake was highest in the pack rat species. Pack rats do not have the specialized physiology of kangaroo rats which permits survival with little water (Schmidt-Nielsen, 1964).

In $N$. micropus and $N$. albigula water intake was inversely related to apparent availability of water in their natural habitat. The $N$. micropus were collected from rocky hillsides with sparse cactus. The $N$. albigula which drank less ( $p<.05$ with Walsh test) than the $N$. micropus, were confined to heavily vegetated washes. Similarly, Lee (1963) found that $N$. lepida from desert habitats drank twice as much as $N$. fuscipes from chapparal habitats.

The chipmunks, which were collected from vegetated areas, drank nearly as little as the two species of rodents from the most arid habitat, $D$. ordii and $O$. leucogaster. ${ }^{2}$ Perhaps the low water need of the chipmunks reflects an adaptation which permits activity during the heat of the day (Robinson, 1959).

Species such as $O$. leucogaster which require limited fluid showed the greatest correspondence between unrestricted and restricted levels of intake. The Neotoma which rely heavily on succulents for water in the wild (Vorheis, 1945) showed the least correspondence. Perhaps pack rats ingest water maximally whenever it is freely available.

Initial intake following deprivation periods was the same as or greater than intake proximate to capture in all species. These data suggest that the water intake of newly captive rodents is high because it follows the experience of relative water deprivation in the wild. The accepted notion that captives drink less over time

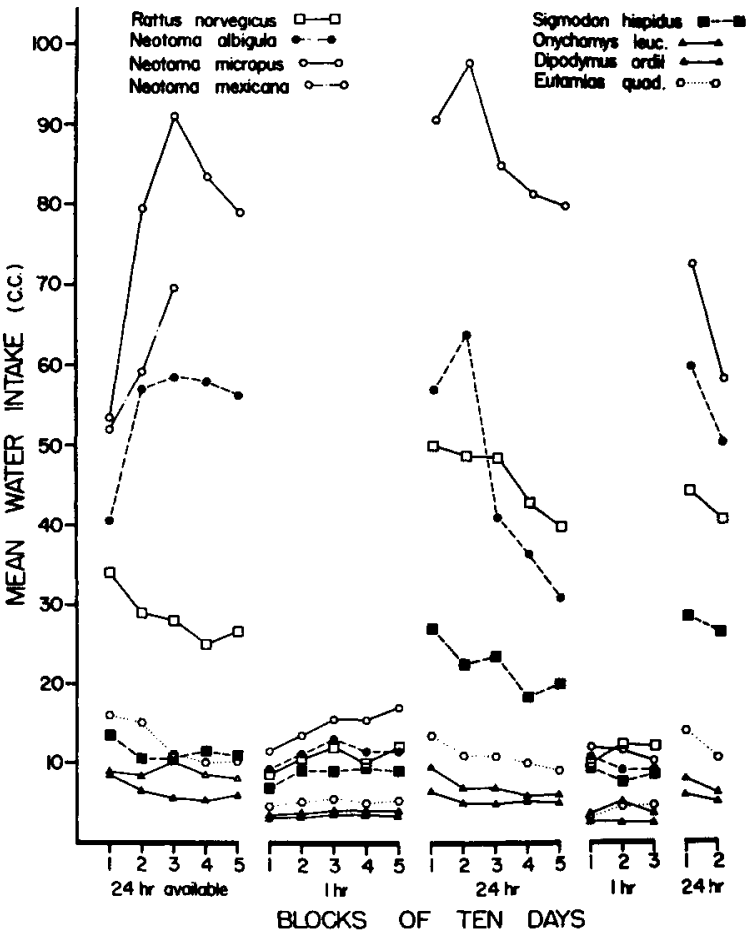

Fig. 1. Mean daily water intake of eight groups of rodents over 200 successive days after capture. The $N$. mexicana were removed from the study at the end of $\mathbf{3 0}$ days when attrition and deaths necessitated feeding them succulents.

because they habituate to the laboratory and become less emotional is also challenged by the finding that undomesticated $R$. norvegicus drink no more than their less emotional counterparts (Boice, in press).

\section{REFERENCES}

BOICE, R. Conditioned licking in wild $\mathrm{F}_{1}$ and domestic Norway rats. $J$. comp. physiol. Psychol, in press.

CHEW, R. M. Water metabolism of mammals. In W. V. Mayer and R. G. Van Gelder (Eds.), Physiological mammalogy, Vol. II. New York: Academic Press, 1965.

HATTON, G. I., \& O'KELLEY, L. I. The effects of maintenance diet on adaptation to food or water deprivation schedules in the rat. Psychon. Sci, $1965,3,267-268$

LEE, A. K. The adaptations to arid environments in wood rats of the genus Neotoma. Univ. Calif. Publ Zool, 1963, 64, 57-96.

RICHTER, C. P., \& MOSIER, H. D. Maximum sodium chloride intake and thirst in domesticated and wild Norway rats. Amer. J. Physiol, 1954, 179, 305-308.

ROBINSON, P. F. Metabolism of the gerbil, Meriones unquiculates. Science, $1959,130,502$.

VORHEIS, C. T. Water requirements of desert animals in the southwest. Univ. Arizona, Agric. Exp. Sta., Tech. Bull, 1945, 86, 487-525.

\section{NOTES}

1. Supported by NIH grant MH 10316-14 to F. A. Logan.

2. Body weights were not measured regularly because pilot studies indicated that handling induced defecation and urination to an extent that water intake measures were affected. Mean body weights of the group at the end of 200 days were as follows: $N$. micropus $-200 \mathrm{~g} ; N$. albigula $-202 \mathrm{~g} ; N$. mexicana-193g; $R$. norvegicus-265g; $S$. hispidus-191g; $E$. quadrivittatus$80 \mathrm{~g} ; D$. ordii $-65 \mathrm{~g} ;$ and $O$. leucogaster $-35 \mathrm{~g}$. 